\title{
Intellectual capital management as an indicator for the development of investment projects at sports institutions *Dr/ Shereen Galal Shehata
}

\section{Introduction}

Intellectual capital has become the real capital of institutions as the cornerstone that plays the main role in the process of innovation and creativity, and it is the leader in the process of change and creativity, and therefore he is able to transform knowledge into value and then to a competitive advantage, so it has become a requirement of the current work environment is the focus On how to develop its intellectual capital to achieve elements that are superior to its competitors, be it on the level of quality of performance, product, service, or other excellence strategies $(9: \leqslant 0)$.

The attention of capital intellectual key management strategy in any organization seeking to grow and develop and strengthen its presence Therefore, the organization that sets before it a strategic goal for development must concern itself with the efficiencies of human capital, and it is recognized that intellectual capital is an investment that has a long-term return, so institutions must make every effort to obtain it( $1: 0 \leq)$.

And intellectual capital is considered the basis for the process of creativity and innovation, and it is the main pillar on which the process of change is based, as it is characterized by its ability to transform knowledge into value and then to a special competitive advantage and the current work environment focuses on how to develop its intellectual capital To achieve higher performance and excellence in services, products and other excellence strategies ( $9: 7 \mathrm{~V})$.

Investment in the sports field has now become one of the most important pillars of investment, such as stocks, real estate, tourism, instrument, etc. This is due to the importance of the investment process

* Assistant Professor, Department of Sports Management and Recreation - Faculty of Physical Education - Assiut University. 
among many economic activities. The investment is a vital and effective element to achieve the process of economic and social development( $\leqslant:$ ro).

From this standpoint, the plan of the Ministry of Youth and Sports came within the framework of the general policy of the state, the issuance of the new investment law No. (72) of (2017) and the issuance of the new sports law No. (71) of (2017) and their interest in investing in the sports field, as the Sports Law of 2017 confirmed in the section on sports investment Article 71 On the need to increase selfresources, explaining the mechanisms and controls of investment from a legislative point of view ( $\mathrm{Y}$ ).

So, the researcher believes that in light of this great importance of intellectual capital, and in light of the volume of investments directed - or that must be directed - to the sports sector, and in light of the deficiency of resources that have become one of the main determinants, and in the midst of intense competition, which is a fundamental feature of the sports environment Economic, it has become necessary to direct the attention and consideration of various sports institutions to realize the importance of intellectual capital and the need to work on its development as the main key to ensure the continuity of the ability to create added value in sports institutions and achieve a strong competitive center through the development of investment projects, therefore this research aims to lay down Highlighting the role of intellectual capital in developing investment projects in sports institutions

\section{Research objective:}

The research aims to identify the role of intellectual capital management in the development of investment projects in sports institutions.

\section{Search questions:}

1- What is the level of intellectual capital management in sports institutions?

2- What are the appropriate investment projects and obstacles to establishing them in sports institutions?

3- Does intellectual capital contribute to predicting the development of investment projects in sports organizations?

\section{The research procedures}

The researcher used the descriptive methodology "survey studies" on a sample of 
rro people from the Ministry
of Youth and
Sports, and boards of directors
and workers of sports
federations, the Olympic
Committee ssports clubs and
youth centers . The sample of
the research was chosen in
a stratified random manner ran
d it reached (325) Individuals
from the research community.

The tools of data collecting

The researcher used forms the questionnaire as a tool for collecting data to achieve the aim of research by designing two forms of questionnaire:

The first questionnaire: what the level of intellectual capital management in sports institutions?

\section{The second questionnaire :}

what the suitable investment projects and the obstacles to establishing them in sports institutions?

The questionnaires form where it was presented to (10) specialized in the sport management.

\section{The validity:}

the survey study results which was performed on 10 people of the society research and out of the basic sample indicated that the tools of data collecting is an accepted validity dealings, since the validity of the first form ranged from $(\cdot \wedge \uparrow \wedge: \cdot .01 r)$ as for the second form, the validity coefficient ranges from 0.472 to 0.866 , that is function at level (0.5) since the value of table R is $(\cdot$ rro $)$

\section{The stability}

The results indicated acceptable stability of transactions through the correlation coefficients between the first applications and the second, during the period of $15 / 7 / 201 \wedge$ till $30 / \wedge / 201 \wedge$ with 15 days apart has coefficients ranged from between correlation $: \cdot 0 \leqslant r$ $(\cdot .11)$ )which function at the level (0.5), where the value of R. Tabular ( $\cdot$ rro) After confirmation of scientific transactions for data collection tools on the sample, application was in the period from 1/08/2018 till 30/08/2018

\section{Discussing the results}

According to the statistical treatments of the research data, the results will be presented in the light of verifying the research goal and answering the following questions:

- The first question: - What is the level of intellectual capital management in sports institutions? 


\section{Table (1)}

Significance of differences between research

sample responses 'relative weight, and average response to a questionnaire on the level of intellectual capital management in sports institutions $(n=325)$

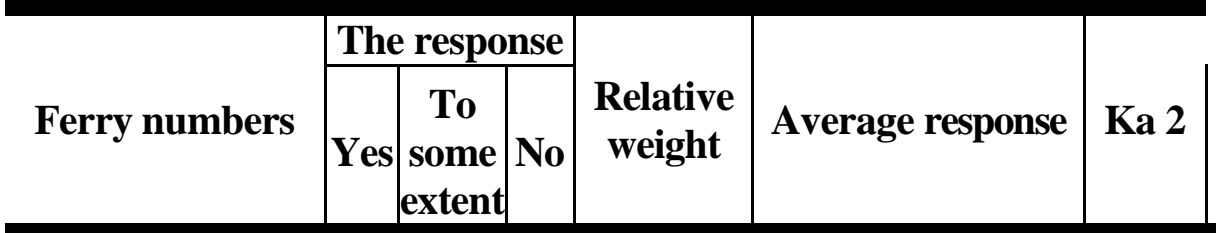

The first axis: the requirements of intellectual capital:

\begin{tabular}{|c|c|c|c|c|c|c|}
\hline 1 & $\overline{~ A . ~}$ & 70 & $1 \wedge$. & 00. & .07 & $\overline{V V Y, 17}$ \\
\hline$r$ & 00 & To & Fro & $\varepsilon V$. &..$\Sigma \wedge$ & TrE, 1 \\
\hline$r$ & 10 & $V$. & $1 V \cdot$ & 070 & .01 & or, 79 \\
\hline$\varepsilon$ & $V T$ & $9 V$ & 100 & 071 & .01 & $r r, \Lambda I$ \\
\hline 0 & 77 & 79 & 19. & OYT & $.0 \leqslant$ & $q r, r q$ \\
\hline 7 & $V$. & Vo & $1 \wedge$. & $0 \leqslant$. & .00 & VI, r \\
\hline V & 90 & 11. & IT. & TYO & $.7 \varepsilon$ & $r, q r$ \\
\hline$\Lambda$ & 19 & 79 & IVV & $00 Y$ & $.0 \mathrm{~V}$ & 70,10 \\
\hline $\begin{array}{l}\text { Average relative } \\
\text { weight and average } \\
\text { response to the axis }\end{array}$ & & & & $0 \leqslant 9,0$ & .07 & \\
\hline
\end{tabular}

The second axis :human capital:

\begin{tabular}{|c|c|c|c|c|c|c|}
\hline 9 & 7 . & To & Tr. & $\varepsilon \wedge$. & $\because \leqslant 9$ & $r \cdot v, \wedge 0$ \\
\hline 1 . & 07 & "ᄉ & | & $\varepsilon \vee 0$ &.$\leqslant 9$ & $r \cdot 9,10$ \\
\hline 11 & 01 & $\varepsilon$. & TrV & $\sum \wedge 1$ & $\because \leqslant 9$ & $197, \leqslant 1$ \\
\hline Ir & 79 & $V V$ & $1 \vee 9$ & $0 \leqslant$. & .00 & $79, \leqslant \leq$ \\
\hline$\pi$ & 71 & $9 \leqslant$ & $1 \mathrm{~V}$ & $0 \leqslant 1$ & .00 & OV, $7 \wedge$ \\
\hline $1 \varepsilon$ & or & ro & rrv & 纟77 &.$\leqslant \wedge$ & r \\
\hline 10th & $7 \wedge$ & 91 & 109 & 009 & $.0 \mathrm{~V}$ & $r q, V$. \\
\hline 17 & 90 & 1.0 & 1YO & Tr. & $.7 \varepsilon$ & $\varepsilon, \mu$ \\
\hline $\begin{array}{l}\text { Average relative } \\
\text { weight and average } \\
\text { response to the axis }\end{array}$ & & & & Or. Y & .04 & \\
\hline
\end{tabular}

The third axis :structural capital:

\begin{tabular}{|c|c|c|c|c|c|c|}
\hline IV & $\overline{V 9}$ & & IV & 000 &. $.0 \mathrm{~V}$ & 09,94 \\
\hline 11 & $\overline{V I}$ & $T Y$ & 194 & OY & $.0 \xi$ & $q \vee, r$. \\
\hline 19 & 71 & ro & rYq & $\varepsilon \wedge r$ &.$\leqslant 9$ & $r \cdot \varepsilon, V r$ \\
\hline
\end{tabular}

Assiut Journal For Sport Science Arts 
Follow Table (1)

Significance of differences between research

sample responses 'relative weight, and average response to a questionnaire on the level of intellectual capital management in sports institutions $(n=325)$

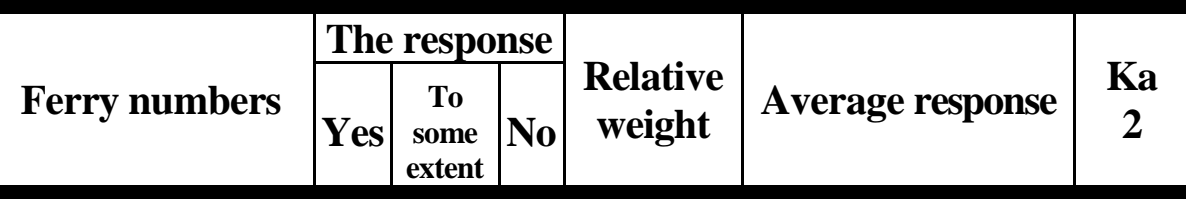

The third axis :structural capital:

\begin{tabular}{|c|c|c|c|c|c|c|}
\hline$r$. & Vo & TE & $Y 17$ & 0.9 &. $.0 Y$ & $1 \neg \wedge, r V$ \\
\hline YI & 01 & TI & |rtry & $\varepsilon V Y$ & $\because \leqslant \wedge$ & $r r q, 0$ \\
\hline TY & $7 r$ & 79 & 195 & 011 & .04 & $1 \cdot 1, \wedge \varepsilon$ \\
\hline Tr & 70 & $V \varepsilon$ & $1 \wedge 7$ & 049 & $.0 \leq$ & Ar,, \\
\hline TE & $\vee \wedge$ & $0 \leqslant$ & 194 & 0 \%o & .00 & $1 \cdot 1,94$ \\
\hline TO & $\lambda r$ & 19 & 104 & $0 \wedge$. & .09 & $r \vee, \vee q$ \\
\hline $\begin{array}{l}\text { Average relative } \\
\text { weight and average } \\
\text { response to the axis }\end{array}$ & & & & r & $.0 \leqslant$ & \\
\hline
\end{tabular}

Fourth Theme :Relationship Capital (Clients: (

\begin{tabular}{|c|c|c|c|c|c|c|}
\hline TY & $9 \mathrm{~V}$ & $1 \cdot r$ & $\mid \overline{|1 Y 7|}$ & 7Y & 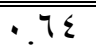 & 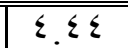 \\
\hline TV & Tr & $\Gamma$. & 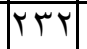 & $\sum \wedge 1$ & $\cdot .59$ & $Y \backslash 7, \vee 9$ \\
\hline$r \wedge$ & 77 & $\varepsilon \varepsilon$ & Y 10 & 0.1 & .01 & $109, \mathrm{VA}$ \\
\hline rq & $7 \wedge$ & 09 & 191 & OY. & .04 & $111, \mathrm{~V}$ \\
\hline$r$. & 09 & $V V$ & $1 \wedge 9$ & Or. & .04 & $91,7$. \\
\hline T & $T r$ & $\Gamma$ & | & $\varepsilon \vee 9$ & .59 & $r / 9,9 r$ \\
\hline r & Y.. & $0 \leqslant$ & 71 & V^. & .189 & $11 \vee, 91$ \\
\hline rr & $r \cdot 1$ & 00 & 79 & $V \wedge Y$ & $\cdot, \wedge \cdot$ & 119,11 \\
\hline$r \varepsilon$ & $\leqslant 0$ & $\varepsilon$. & $r \varepsilon \cdot$ & $\leqslant 00$ & $\because \varepsilon V$ & $r \leq \cdot, 17$ \\
\hline $\begin{array}{l}\text { Average relative } \\
\text { weight and average } \\
\text { response to the axis }\end{array}$ & & & & $00 \leqslant, 11$ & .09 & \\
\hline
\end{tabular}

Axis $\mathrm{V}$ :head of capital creative:

\begin{tabular}{|c|c|c|c|c|c|c|}
\hline ro & 71 & ro & Frq & $\sum \lambda T$ &..$\leqslant 9$ & $\overline{r \cdot \varepsilon, V r}$ \\
\hline rq & 09 & $V V$ & 119 & Or. & $.0 \%$ & $91,7$. \\
\hline$\overline{r V}$ & $7 \varepsilon$ & $0\}$ & $r \cdot V$ & $0 . \mathrm{V}$ & $.0 Y$ & $1 \% 0, Y_{1}$ \\
\hline rᄉ & 91 & $1 \ldots$ & $T r V$ & TII & $.7 \varepsilon$ & $\varepsilon, \wedge \varepsilon$ \\
\hline$r q$ & 07 & $\mu$ & TrN & $\varepsilon 71$ & $\cdot . \leqslant \wedge$ & KTO,79 \\
\hline
\end{tabular}

Assiut Journal For Sport Science Arts 
Follow Table (1)

Significance of differences between research

sample responses 'relative weight, and average response to a questionnaire on the level of intellectual capital management in sports institutions $(n=325)$

\begin{tabular}{|c|c|c|c|c|c|c|}
\hline \multirow[b]{2}{*}{ Ferry numbers } & \multicolumn{3}{|c|}{ The response } & \multirow[b]{2}{*}{$\begin{array}{l}\text { Relative } \\
\text { weight }\end{array}$} & \multirow[b]{2}{*}{ Average response } & \multirow[b]{2}{*}{ Ka 2} \\
\hline & Yes & $\begin{array}{c}\text { To } \\
\text { some } \\
\text { extent }\end{array}$ & No & & & \\
\hline$\varepsilon$. & $\Lambda \wedge$ & $V \cdot$ & $17 V$ & ovi & .09 & $\leqslant 9,10$ \\
\hline \&) & 09 & r. & rrt & $\varepsilon V T$ &.$\leqslant 9$ & Yrq,0T \\
\hline$\varepsilon Y$ & 79 & 97 & 17. & 009 & $.0 \mathrm{~V}$ & $\varepsilon \cdot \mu$ \\
\hline$\Sigma \Gamma$ & 79 & or & $r \cdot r$ & 017 & $.0 \mathrm{~T}$ & IYO, YV \\
\hline $\begin{array}{l}\text { Average relative } \\
\text { weight and average } \\
\text { response to the axis }\end{array}$ & & & & or $\varepsilon, 11$ & $.0 \leqslant$ & \\
\hline \multicolumn{7}{|c|}{ The sixth axis: performance evaluation and measurement: } \\
\hline$\varepsilon \leqslant$ & 07 & $\leqslant 0$ & TYS & $\varepsilon \wedge Y$ &.$\leqslant 9$ & $\overline{1 \wedge 0, \wedge 1}$ \\
\hline$\leqslant 0$ & $7 \pi$ & 07 & $r \cdot T$ & $0 . V$ & $.0 Y$ & |r, \\
\hline$\varepsilon 7$ & 71 & rs & rr. & $\varepsilon \wedge 1$ & $\because \leqslant 9$ & $r \cdot \Lambda, \mu r$ \\
\hline$\varepsilon V$ & $7 Y$ & س & Tr. & $\varepsilon \wedge Y$ & $\therefore \leqslant 9$ & $r \cdot \Lambda, \wedge 0$ \\
\hline$\varepsilon \Lambda$ & $9 \varepsilon$ & $\wedge \wedge$ & $1 \leq r$ & $7 \cdot 1$ & $.9 r$ & 17,11 \\
\hline$\leqslant 9$ & VY & 7. & 194 & org & $.0 \leqslant$ & $99,9 r$ \\
\hline 0. & $0 \wedge$ & 71 & $r \cdot T$ & 0.1 & .01 & $\overline{M r, I T}$ \\
\hline 01 & $7 \varepsilon$ & 9. & $\mid 1 \times 1$ & $0 \leqslant T$ & .07 & $0 \mathrm{~V}, 0$. \\
\hline \multicolumn{4}{|c|}{$\begin{array}{l}\text { Average relative weight and } \\
\text { average response to the axis }\end{array}$} & $010, \lambda \mathrm{V}$ & .01 & \\
\hline \multicolumn{4}{|c|}{$\begin{array}{l}\text { Average relative weight and average } \\
\text { response to the questionnaire as a whole }\end{array}$} & or, ,1 & .00 & \\
\hline
\end{tabular}

Minimum confidence $=0,62$ Maximum confidence $=0,72$

Table (1) The value of $\mathrm{Ka} 2$ is a function of the degree of freedom (2) and the level of significance $(0.05)=5.99$

The researcher of the due weakness in the capital of intellectual requirements in sports institutions to a lack of interest in the process of Polarization industry and the revitalization and preservation of capital intellectual as requirements for capital intellectual sports institutions 'despite the perception of contemporary sports 


\section{7}

institutions based to

the

development of resources by achieving economic development and profitability need to attract industry and the revitalization and preservation of the intellectual capital that has the ability to add ? and creativity and to improve working methods rincluding contributing to seize the right opportunities so must to be the attention of the largest in this side and work on the maintenance The human element of the statute of limitations and taking into account the staff 's concerns and desires to work and that the attention of individual for Special them in Their various sites.

Also there are some deficiencies in the human capital by sports institutions 'which indicate that sports institutions do not to wns the number of sufficient human resources who have practical experience specializing in investment to carry out their work efficiently and effectively and see the researcher that he should pay more attention to investing in human capital By developing and training workers ‘ because it is the real capital within sports institutions as it is able to convert the unique knowledge into an economic value through the development of both "human capital," and this is why the focus on generating economic value for organizations has shifted from the exploitation of material resources to the exploitation of intellectual resources, which Inevitably contributes to increasing productivity in order to achieve the development of Egyptian sport at the national and strategic levels.

The researcher also attributed the weakness in the structural capital to the fact that most sports institutions do not adopt an organizational structure with a special investment management, just as sports institutions do not develop their organizational structure according to investment developments and the organizational structure in sports institutions does not guarantee the flow and validity of the knowledge necessary for all levels of management ، and the researcher interprets That may be due to the lack of clarity of some of the various specializations and responsibilities within sports institutions, which reduces the opportunities for structural capital to exist, so the researcher believes that the presence of a good organizational structure within 
sports institutions contributes to achieving the vision and mission of the institution, thus achieving the development of investment in sports institutions.

The researcher attributes the shortcomings in the capital of relationships (clients) to the fact that sports institutions do not determine the quality and numbers of clients who benefit from their services and gain their trust and loyalty as well as there are no clear mechanisms with the institution to follow up on observations and complaints related to customer service operations and are not keen to know investment plans and how to implement them for their examples Of the institutions in the developed countries and compare them with the aim of developing work with them, as well as the sports institutions do not have websites and electronic means of communication in order to facilitate the provision of services to the beneficiaries even though they have databases on all the beneficiary bodies and the beneficiary customers and the needs they need to try to achieve them and hold training courses and conferences In the field of investment and financing, the researcher attributes this to the presence of some organizational and administrative obstacles within sports institutions that hinder the nature of work and determine external relations with its clients and the lack of a clear vision of the concept of this relationship.As the changing conditions and conditions imposed by the recent changes, and the novelty of renewable technology, the efficiency of the elements used in the performance of the institution weakens in front of the challenges of modern means, which obliges the administration to follow developments and adapt to them, to bring about the continuous development there.

The researcher indicates the result in the creative capital axis that the management of the institution does not attempt to estimate the value of the intellectual capital available to it and develop it as it does not discover the problems that exist in investment projects to solve them and does not make the required change in favor of the success of investment projects and does not seek to find new methods in working with investment projects It does not provide sufficient 
support for creativity and innovation in the organization, and the administration is not keen on providing rewards and incentives for creative work. The researcher believes that the work in sports institutions should be enriched with a number of innovative and renewable investment ideas, the production of unconventional or repeated ideas, and a positive change or renewal in the mechanisms of work in investment projects.

The researcher attributes this result in the evaluation and performance measurement to the fact that sports institutions do not identify and support strengths and weaknesses and address them for workers in investment projects as well as there is no periodic evaluation of the performance of workers in investment projects and their validity and efficiency are not measured to link the results of performance evaluation and requirements and training needs and therefore Determine the types of training and development programs in investment projects, as there are no appropriate means to measure the intellectual capital to take corrective measures to improve the institution's position to continue to apply its strategy for investment projects, and new policies that are compatible with change are not created through continuous evaluation of investment projects, and the researcher believes that it is necessary and necessary From performing the process of measuring and evaluating the performance of the organization as a whole and the investment projects in it, because it reflects the amount of work that has been accomplished, and It contributes to making sure that the improvement and development that has been planned to have already taken place, identifying and analyzing risks and difficulties facing the corporation in general and its investment projects in particular in its path to achieving its goals and proposing appropriate solutions to address them as well as supporting the processes of improving services and activities that it provides and developing by measuring the quality of services And customer satisfaction.

And this was confirmed by the study" Mustafa Abu Bakr " ( ( I) ( $(\cdots \vee V)$ the study

"Catherine, Patrick ( $Y .9$ )" ((1))Adila Qurashi (2008 ( '(^)and Marwan Darwish 
(2006 • ( $\cdot$ •) (Abdullah Ali (Y * 9) ، " ( $\vee$ )the study of Mahmoud Rousan Mahmoud Ajlouni "(2010 ، ( ( ) (the study "Taha Mahmoud Hussein" (2010 ( (\urcorner$)$ study " Mitchell $(\uparrow \cdot 1 \cdot))$ ، ( $₹$ )b ( The necessity of making use of all the human resources component, as this leads to achieving job performance within the organization to the extent required in achieving the good management vision of the organization ' as the intellectual capital provides information that will draw attention towards the way the organization is employed Of its resources, and its long-term outlook.

With this, the researcher has answered the first question of the research, which states: "What is the level of intellectual capital management in sports institutions?"

2. The second question: What are the appropriate investment projects and obstacles to establishing them in sports institutions?

Table ( $r$ )

An indication of the differences between research

sample responses 'relative weight, and mean response to a questionnaire Investment projects in sports institutions $(n=325)$

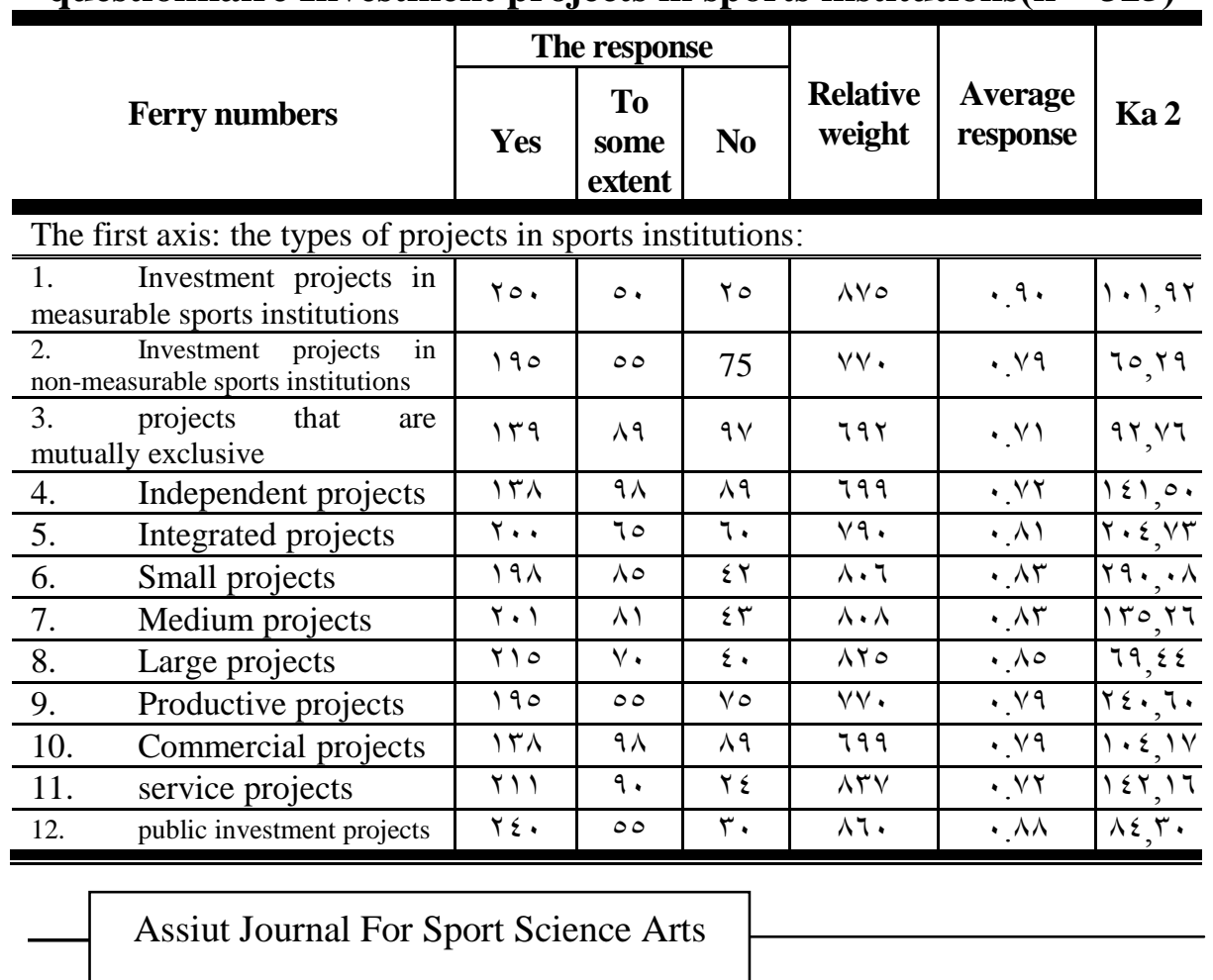




\section{Follow Table ( $r$ )}

An indication of the differences between research

sample responses 'relative weight, and mean response to a

questionnaire Investment projects in sports institutions $(n=325)$

\begin{tabular}{|c|c|c|c|c|c|c|}
\hline \multirow[b]{2}{*}{ Ferry numbers } & \multicolumn{3}{|c|}{ The response } & \multirow[b]{2}{*}{$\begin{array}{l}\text { Relative } \\
\text { weight }\end{array}$} & \multirow[b]{2}{*}{$\begin{array}{l}\text { Average } \\
\text { response }\end{array}$} & \multirow[b]{2}{*}{ Ka 2} \\
\hline & Yes & $\begin{array}{c}\text { To } \\
\text { some } \\
\text { extent }\end{array}$ & No & & & \\
\hline Joint investment projects & $r \cdot 7$ & 9. & rq & $\Lambda T V$ &.$\wedge 0$ & $9 Y . V 7$ \\
\hline replacement projects & 199 & $\Lambda$ & $\varepsilon 7$ & $\Lambda \cdot r$ &.$\wedge r$ & $7 r, v V$ \\
\hline Expansion projects & IT人 & 91 & 19 & 799 & $\because V Y$ & $11 Y, T$ \\
\hline Individual projects & 190 & 00 & Vo & $V V \cdot$ & $\because \vee 9$ & $1 \cdot 1,94$ \\
\hline Collective projects & Y10 & $V \cdot$ & $\varepsilon$. & Aro &.$\wedge 0$ & 70, Y9 \\
\hline Fund companies & $r \varepsilon$. & 00 & r. & 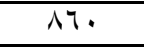 & $\because \wedge \Lambda$ & $\mathrm{VA}, 79$ \\
\hline $\begin{array}{l}\text { Average relative weight and } \\
\text { average axis response }\end{array}$ & & & & VAq.VY &.$\wedge 1$ & \\
\hline \multicolumn{7}{|c|}{ The second axis: the obstacles of projects in sports institutions: } \\
\hline 19. Financial Obstacles & $9 \mathrm{~V}$ & 149 & $\wedge 9$ & 701 & $.7 \mathrm{~V}$ & IT, M \\
\hline 20. & $7 \leq$ & 94 & 179 & $0 \leqslant 0$ & .07 & $0 \leqslant, 0 \wedge$ \\
\hline 21. & YE. & 00 & r. & А५. & $\because \wedge \wedge$ & $V \wedge, 79$ \\
\hline 22. & 91 & ITA & 19 & 709 & .71 & 171,49 \\
\hline Technical obstacles & $\wedge 1$ & 7. & $1 \wedge \varepsilon$ & $0 \leqslant V$ & .07 & $\wedge I, M_{1}$ \\
\hline 24. & $0 \wedge$ & $\vee \wedge$ & 119 & 019 & .01 & 91,90 \\
\hline $\begin{array}{l}\text { 25. Administrative and } \\
\text { Organizational Obstacles }\end{array}$ & $9 V$ & 149 & 19 & 701 & $.7 V$ & rس, \\
\hline 26. & 91 & 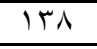 & 19 & 709 & $\because \mathrm{VA}$ & IT,OT \\
\hline 27. & Vo & $r \cdot$ & 0. & $7 \times 0$ & .79 & $r \cdot 1,7 r$ \\
\hline 28. & $V Y$ & 19 & $17 \varepsilon$ & 001 & $.0 \mathrm{~V}$ & $\varepsilon \leqslant, Y \leqslant$ \\
\hline 29. & 91 & $1 \leqslant 7$ & $\wedge \wedge$ & 701 & $.7 \mathrm{~V}$ & 19,79 \\
\hline Marketing Obstacles & VI & 9. & $17 \varepsilon$ & $00 \mathrm{~V}$ & $.0 \mathrm{~V}$ & $\varepsilon \varepsilon, 0 V$ \\
\hline 31. & 91 & $1 \leqslant 7$ & $\wedge \wedge$ & 701 & $.7 \mathrm{~V}$ & rr, ro \\
\hline 32. & 94 & 19 & $1 \leq \pi$ & $7 \ldots$ & $.9 r$ & 17,71 \\
\hline Legislative Obstacles & $1 \wedge \wedge$ & $0 \wedge$ & $\sqrt{99}$ & Voq & $\because \vee \wedge$ & $\wedge 9,9 r$ \\
\hline 34. & 91 & $1 \leqslant 7$ & $\wedge \wedge$ & 701 & $.7 V$ & $1+, 1$ \\
\hline 35. & 97 & $1 \cdot r$ & ITV & 719 & $.7 \pi$ & AT.TV \\
\hline 36. & $V 7$ & $\mathrm{~V} \cdot$ & 189 & $0 \leqslant V$ & .07 & $79, \Gamma_{1}$ \\
\hline \multicolumn{4}{|c|}{ Average relative weight and average response to the axis } & $7 \leq Y .11$ & .77 & \\
\hline \multicolumn{4}{|c|}{$\begin{array}{l}\text { Average relative weight and average response to the } \\
\text { questionnaire as a whole }\end{array}$} & 701 & $. \vee \leqslant$ & \\
\hline
\end{tabular}

Minimum confidence $=0,62$ Maximum confidence $=0,72$

The value of $\mathrm{Ca}$ is a function of the degree of freedom (2) and the level of significance $(0.05)=5.99$ 
The first axis shows the " types of projects sports institutions " that there is a strong indicator of a sample agreement research on the types of investment projects in the sports institutions represented in measurable projects and non -measurable ، and prohibitive exchange projects, independent projects, and projects of integrated, small projects, and projects Medium And large projects, production projects, commercial projects:, service projects, public investment projects, joint investment projects, substitution projects, substitution projects, expansion projects, individual projects, group projects, capital companies.

As "Hassan Al-Shafi" $(r)(r \ldots \tau) \quad$ states that investing in sports institutions aims to increase the capital of sports institutions by employing capital in various sports activities, which leads to an exchange of benefits between investors to invest their money and between different sports institutions to invest their material and human capabilities necessary for sports activities (Player Administrative - Audience.( The second axis shows the"disabled projects sports institutions "that there is a strong indication of the sample agreement on research projects that obstacles to sports institutions are in the) financial constraints, technical constraints, administrative and regulatory constraints, marketing constraints, legislative obstacles)

Was where the funding constraints in the weakness of multiple sources of funding for investment projects in sports institutions, and is difficult to attract investors to finance investment projects although the banks provide loans to credit medium or long-term financing of the difficulty of investment projects to obtain the capital to finance investment projects of sports institutions by offering the shares In securities or the issuance of borrowing bonds.

As for technical constraints, they are represented in the fact that there are no clear technical and financial policies and procedures for setting up investment projects in sports institutions, and there is no technical support system for investment projects in sports institutions and attracting investors.

And with regard to marketing constraints, there are no regular marketing outlets and an e-commerce site and electronic display of investment projects products 
and services for sports institutions for the domestic and external consumer ' and there is a weakness in the availability of sufficient experience in marketing and investment of investment projects in sports institutions ، and the difficulty of determining the value of profits through establishing projects Sports investment within sports institutions so that investors have full confidence in achieving material gains.

Legislative constraints indicate that there is a law to develop investment projects for sports institutions, but there is a lack of awareness of these legal legislations and executive procedures for investment

\section{Table ( $(r)$}

projects in sports institutions, and there are no legal facilities and incentives that contribute to the liberalization and launch of these projects ، and there are no rules to ensure coordination between the bodies supporting investment projects Sports institutions.

In this t the fact that the researcher has answered t to question the second search 'which provides for the" What is the appropriate investment projects and obstacles set up in the sports institutions"?

$r$-The third question: - Does intellectual capital contribute to the prediction of achieving development for investment projects in sports institution?

Multiple regression analysis between the axes of the intellectual capital questionnaire and the types of investment projects in sports institutions $\mathbf{n}=325$

\begin{tabular}{|c|c|c|c|c|c|c|c|c|c|c|}
\hline Independent variable & $\begin{array}{c}\text { Dependent } \\
\text { variable }\end{array}$ & $\begin{array}{c}\text { Correlation } \\
\text { coefficient } \\
\mathbf{R}\end{array}$ & $\begin{array}{c}\text { Common } \\
\text { contrast } \\
\text { Rsquare }\end{array}$ & $\begin{array}{l}\text { Ratio } \\
\text { value } \\
) \mathbf{F}(\end{array}$ & $\begin{array}{c}\text { Statistical } \\
\text { significance }\end{array}$ & $\begin{array}{c}\text { Hard } \\
\text { value } \\
\text { Constant }\end{array}$ & $\begin{array}{c}\text { The } \\
\text { weight of } \\
\text { the } \\
\text { normal } \\
\text { gradient } \\
\text { isa value } \\
\text { B }\end{array}$ & $\begin{array}{c}\text { Standard } \\
\text { regression } \\
\text { weight is } \\
\text { a value } \\
\text { Beta }\end{array}$ & Values T & $\begin{array}{c}\text { Statistical } \\
\text { significance }\end{array}$ \\
\hline $\begin{array}{l}\text { Intellectual capital } \\
\text { requirements }\end{array}$ & \multirow{5}{*}{$\begin{array}{l}\text { And the } \\
\text { types of } \\
\text { investment } \\
\text { projects in } \\
\text { sports } \\
\text { institutions }\end{array}$} & \multirow{5}{*}{ 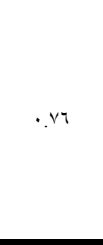 } & \multirow{5}{*}{$\because .01$} & \multirow{5}{*}{$V T, Y \wedge$} & \multirow{5}{*}{ D. } & \multirow{5}{*}{$1 \cdot$, AT } & $\because, v_{-}$ & $\cdot, \cdot \varepsilon_{-}$ & $\cdot . \leqslant 7$ & Is D. \\
\hline Human capital & & & & & & &. .01 & $\cdot, r \cdot$ & $\varepsilon, 7$. & D. \\
\hline Structural capital & & & & & & &. .49 & $\cdot r T$ & r, & D. \\
\hline $\begin{array}{l}\text { Relationship Capital } \\
\text { (Customer( }\end{array}$ & & & & & & &. .00 & $\cdot r v$ & $r, \leqslant \leqslant$ & D. \\
\hline Creative capital & & & & & & & $\cdot, r \Lambda_{-}$ & $\cdot, 11$ & $1,1 \mathrm{~V}$ & Is D. \\
\hline $\begin{array}{l}\begin{array}{l}\text { Performance } \\
\text { evaluation } \\
\text { measurement }\end{array} \text { and } \\
\end{array}$ & & & & & & & $\because r$. & .10 & $1, r \cdot$ & Is D. \\
\hline $\begin{array}{l}\text { The total score } \\
\text { for the intellectual } \\
\text { capital questionnaire }\end{array}$ & & $\cdot v \leqslant$ &. .00 & rqo, rq & D. & $11, r_{0}$ & 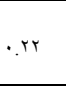 & $\cdot v \varepsilon$ & 19,11 & D. \\
\hline
\end{tabular}


Table ( $\varepsilon$ )

Analysis of multiple regressions between the axes of the human capital development questionnaire and the ability to face crises in the Ministry of Youth and Sports. Sample of the research $n=325$

\begin{tabular}{|c|c|c|c|c|c|c|c|c|c|c|}
\hline $\begin{array}{l}\text { Independent } \\
\text { variable }\end{array}$ & $\begin{array}{c}\text { Dependent } \\
\text { variable }\end{array}$ & $\begin{array}{c}\text { Correlation } \\
\text { coefficient } \\
\mathbf{R}\end{array}$ & $\begin{array}{c}\text { Common } \\
\text { contrast } \\
\text { Rsquare }\end{array}$ & $\begin{array}{l}\text { Ratio } \\
\text { value } \\
\text { )F( }\end{array}$ & $\begin{array}{c}\text { Statistical } \\
\text { significance }\end{array}$ & $\begin{array}{c}\text { Hard } \\
\text { value } \\
\text { Constant }\end{array}$ & 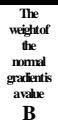 & $\begin{array}{c}\text { Standard } \\
\text { regression } \\
\text { weight is } \\
\text { a value } \\
\text { Beta }\end{array}$ & Values T & $\begin{array}{c}\text { Statistical } \\
\text { significance }\end{array}$ \\
\hline $\begin{array}{l}\text { Intellectual } \\
\text { capital } \\
\text { requirements } \\
\end{array}$ & \multirow{7}{*}{$\begin{array}{c}\text { Obstacles } \\
\text { to suitable } \\
\text { investment } \\
\text { projects in } \\
\text { sports } \\
\text { institutions }\end{array}$} & \multirow{6}{*}{$\because \lambda r$} & \multirow{6}{*}{$\cdot \pi$} & \multirow{6}{*}{$11 r, \cdot r$} & \multirow{6}{*}{ D. } & \multirow{6}{*}{11,79} & I, & 7.07 & Q,AV & D. \\
\hline $\begin{array}{l}\text { Human } \\
\text { capital }\end{array}$ & & & & & & & - & , Y & $r, \pi r$ & D. \\
\hline $\begin{array}{l}\text { Structural } \\
\text { capital }\end{array}$ & & & & & & & .17 & $\because 9$ &,,$\cdot v$ & IsD. \\
\hline $\begin{array}{l}\text { Relationship } \\
\text { Capital } \\
\text { (Customer( } \\
\end{array}$ & & & & & & & $\because r$ & r & .97 & IsD. \\
\hline $\begin{array}{l}\text { Creative } \\
\text { capital }\end{array}$ & & & & & & & $\because, \sim$ & 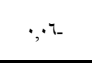 & .00 & IsD. \\
\hline $\begin{array}{l}\text { Performance } \\
\text { evaluation and } \\
\text { measurement }\end{array}$ & & & & & & & .07 & .97 & r, Yo & D. \\
\hline $\begin{array}{l}\text { The total score } \\
\text { for the } \\
\text { intellectual } \\
\text { capital } \\
\text { questionnaire }\end{array}$ & & $\cdot 17$ & .01 & $\leq \leqslant \leq, O V$ & D. & $11, T V$ & • & $\cdot 17$ & $r, \cdot q$ & D. \\
\hline
\end{tabular}

The researcher attributes of the result associated with tables ( $\Gamma$ ، $\varepsilon$ ) that capital intellectual of the most important variables that can contribute fully contribute to both the development of appropriate types of investment projects ، sports institutions and meet the investment projects constraints sports institutions ' and thus can predict both.

When the sports institutions very well of economic the value nationalism and the strategy of capital intellectual by management in a manner based on the human and intellectual assets development work to create distinct capabilities in the knowledge and expertise of human resources and which the enable them new and innovative offer ideas in the light of climate structural founders Depends on creativity and innovation

In the light of the results of the previous table, the researchers see the importance of caring with the following results:

\section{Conclusions:}

1- The weak level of intellectual capital in sports institutions.

2- The administrative leaderships in sports institutions and investment projects neglect the concept of 
intellectual capital and the advantages that can be achieved from behind it 3- There are various types of investment projects suitable for sports institutions represented in measurable projects and nonmeasurable ، and prohibitive exchange projects, independent projects, and projects of integrated, small projects, and projects are medium and large projects, productive projects, commercial projects :, service projects, public investment projects, Joint investment projects, affiliate projects, affiliate projects, expansion projects, individual projects, group projects, capital companies.

4- There are obstacles to facing investment projects in sports institutions, namely (financial constraints, technical constraints, administrative and organizational constraints, marketing constraints, legislative constraints)

\section{Recommendations}

For the need sports institutions to direct their energies towards the promotion and development of intellectual capital in investment projects through:

1- The need to activate the concepts of intellectual capital within the organizational structure of sports institutions as independent organizational units as well as the development of existing structures in accordance with the concepts and functions of human resources management as a philosophy and not as procedures, which helps to encourage individuals to innovate and creativity by making room for them to present innovative ideas aimed at superiority and excellence.

2- The administration gives more importance to strengthening human, structural, and creative capital and relationships through the participation of workers in formulating procedures and policies manuals as well as strategic and operational plans for investment projects in sports institutions.

\section{References}

1. Ahmad Al-Mafraji, Ali Saleh : Expenditure on intellectual capital and its impact on the success of industrial companies researc $\mathrm{h}$ presented to the scientific conference of the University of Applied Sciences Private, Amman, Jordan. r... r ،

2. Awais Atwa Al-Zant : Fundamentals of Project Evaluation and Feasibility Studies, Part One, Academic Library. 199r ،

3. Hassan Ahmed ElShafei : Investment and 
Marketing in Physical

Education and Sports, Alexandria, Sidi Bishr, AlWafaa Printing and Publishing House Y.. T ، AD.

4. Hassan Ahmad AlShafei : Feasibility Studies and Small Projects in Physical Education and Sports, Dar AlWafaa for Print and Publishing World, Alexandria Y ... ، AD.

5. Saad Saleh on : Capital management in intellectual business organizations, Dar Yazouri for Publishing and Distribution,Amman Y..q m.

\section{Taha Mahmoud}

Hussein : Investing in knowledge capital and a course in building the competitive advantage of the organization, Scientific Journal, No. (2), Faculty of Commerce, Helwan University. $Y_{\cdot}$. $\cdot$ ،
7.
Abdullah
Ali :

Measuring Intellectual Capital, Journal of Statistics and Applied Economics ، Volume 6, First Issue $r^{\prime} .9$ ، CE.

8. Adela Abdullah AlQurashi : Administrative Creativity in Change

Management at Principals and Aids for Primary Schools in Makkah Al-Mukarramah, Unpublished Master Thesis, Umm Al-Qura University, Makkah. Y.. A 。

9. Mahmoud Ali AlRousan, Mahmoud Muhammad Al-Ajlouni : The Impact of Intellectual Capital on Creativity in Jordanian Banks
(Field Study), Damascus University Journal for Economic and Legal Sciences, Volume 26, Second Issue, $201 \cdot$ AD.

10. Marwan Darwish: Knowledge management and its role in achieving administrative creativity among the managers of bank branches operating in Palestine, research presented to the second conference of the Faculty of Economics and Administrative Sciences, Journal of the University of Applied Sciences Private, Volume 2 No. 15, Amman Jordan, 2006 AD.

\section{Mustafa Mahmoud}

Abu Bakr : Human resources ( the entrance to achieve competitive advantage), Press the Faculty of Commerce, Cairo $20 \mathrm{v} \cdot \mathrm{m}$.

12. Ministry of Youth and Sports: The new Sports Law, the Arab Republic of Egypt 0.2017

13. Catherine, Patrick, Harrington : (2009).

Managing intellectual capital for a sustaing competitive advantage in the lrish tourism industry in: the tourism and hospitality research in Ireland conference .

14. Mitchell.h: (2010) study a model for managing Intellectual capital to generate weath, a thesis of doctor of philosophy in business, new Zealand, massey university. 